Предраг Пеца Поповић https://doi.org/10.18485/ai_vnia_bora_djordjevic.2018.1.3 новинар и публициста из Београда $\quad \begin{aligned} & 821.163 .41 .09-1 \text { Радичевић Б. } \\ & \text { 821.163.41.09-1 Ђорђевић Б. }\end{aligned}$

\title{
ПОЕЗИЈА, МУЗИКА И СУДБИНЕ - ИЗДАНЦИ ИЗ ВИТА РЕБРА БРАНКА РАДИЧЕВИЋА
}

Колико у једном тако немузикалном језику велики песник, ако то јесте, може примером свог говора, ритма и музикалношћу стиха инспирисати поезију на папиру и ауторе стихова за музику?! Мислим на онога о коме је Исидора Секулић записала „првак и првенац... умро је млад, сувише гладан а оставио такве почетке поезије који се не даду измерити са његовом смрћу." Хоћу и о његовим следбеницима до дана данашњег, понајвише о Бори Ђорђевићу и Марку Шелићу Марчелу. Имају у поезији и судбини нешто што их повезује.

Кључне речи: Бранко Радичевић, Бора Ђорђевић, Марко Шелић Марчело

Бранко Радичевић је неостарели родоначелник српске лирике. Први школовани музичари ових простора из друге половине XIX века одмах су га прихватили, а век касније проносиоци популарне музике следили и имитирали у свом стваралаштву. Поета елементарних мушких осећања, утемељитељ простора за распусне и чулне лирске приче, утицао је на рађање српске грађанске музике и проширио простор за слободну игру народним језиком. Због њега је епско певање замењено лирским, са гусала се храбро пошло ка европском инструментаријуму и мелодијама. Увео је „непристојност” и легализовао бећарце, претеча је неспутаног певања које ће у потпуности бити 
прихваћено тек век касније у временима рокенрола. Истовремено, био и остао пример младог и лепог идола који је умро пре него што је стигао да остари.

Тај цитат „Много хтео, много започео” више је од епитафа урезаног у камени постамент споменика на Стражилову. Управо такав мементо даје додатни, велики и људски смисао једном неправедно кратком животу! Осећај једне недовршености, легат од свега педесет четири песме које у националну књижевност уводе нове мотиве и расположења, век и по је алиби и изазов за песмотворце жељне да се огласе и буду саслушани. Бранко је та весела фрула што се као урок мота по генерацијама, та сета елегије што нас уводи у концертне сале и набрекао стих у који уме да прерасте хук стадиона.

\section{Живот је само сенка што хода}

Усамљена појава једног времена отишла је прерано не дочекавши победу своје поетике. Следећи нараштаји песника доводе до краја његов поетски „вјерују” с којим се романтизам утврђује као преломна тачка и ствара основа за оглашавање каснијих првака нашег језика. Бранко је велики почетак заједничке поезије, али не у једном правцу, него у ширини и слободи певања. То је разлог ьегове вечне младости.

У књизи Постань Старог завета стоји: Бог створи Адама од праха зематског и удахну у нега живот, начинивши га живим бићем. Бог Адаму начини жену од неговог ребра. Даде јој име Ева.

Када су Бранкови посмртни остаци путовали од Беча ка Стражилову, а томе је тачно 135 година, нестадоше два ситна комада инвентара: „Један део од вита ребра и карика од жутог лима са мртвачког сандука." 
Верујем у легенду што тихо кружи међу посвећенима. Ону што каже како тај део песника лебди над овом земљом као и онај чланак Доситејевог кажипрста. Када се негде и некад под модрим чадором српским сусретну те две ситне кости - споји их жута лимена карика - и тако се најави значајна личност овог језика, овог народа и заједничког певања.

Годинама не сумњам: из Бранковог вита ребра, из тих 4 несталих сантима за последњих век и по огласиле су се громадне поете Змај и Ракић, Шантић и Дучић, Драинац и Миљковић, Црњански и Раичковић, Павловић и Попа, Антић и Ршумовић, Матија и Радовић, Либеро Марковић и Зубац, Петровић и Трифуновић, али и највећи „махери у писању углазбљених стихова односно музиком прошивене поезије”.

Искуство сложеног односа поезије и музике показује да не постоје непевљиви или немузикални песници и писци. Бранко је, да поновим, посебан случај нашег песниковања, као човек сав од музике па није чудо што је његова поезија, пуна метричког и еуфоничног склада, прихваћена од композитора, других песника и обичног народа. До сада музиком је окићено и обрађено 35 песама из његовог опуса. О томе музиколог Стана Ђурић-Клајн каже: „Музика у Бранковом тексту чује се од почетка до краја у целокупном стварању његовом. Музикалност његове фразе, многобројне идеје и слике узете из области музике (певање, свирка тамбурице, кола) везују га тесно за музику."

\section{Сликати стварност аранжирајући речи}

Код Сократа налазимо да је поезија „нешто лако и крилато". Преведено на ситуацију нашег језика, Бранко је наш најлакокрилатији поета. Иако је умро у временима када је критика мислила да је доба поезије прошло, 
те песме живе, као и пророчки стих „Ал' што певах неће пропанути".

Модерна српска поезија укоренила се и винула ка висовима с Бранком Радичевићем.

Не без разлога, знаменити Милан Кашанин пише: „Бранкова поезија је свежина младе траве, разиграност веверица, глас лирског тенора. Све је младо у тим песмама. Млад је песник који их је испевао, млад је језик на ком су речене, млада су осећања која их носе и младе мисли које у њима кликћу. У том песнику и у тим песмама је лепота свитања. Као и свитање, та поезија не греје и не пали: она разведрава. Такве умиљатости и безбрижности, такве веселости и безазлености неће се наћи у песмама ни код једног српског песника. Јер никоме свет није био тако диван, ни тако створен за радост и осмех као том неизлечиво болесном младићу.”

Време у којем живимо и у чијем протицању учествујемо, време је бруталне угрожености свега тананог, нежног, љупког и светог. Зато су стихови првопесника као инспирација за музичку надградњу увек догађај своје врсте.

Није то случајно, ни ново откриће...

У Божанственој комедији, у XXVI певању „Чистилишта", Данте херметичног трубадура Данијела назива „најбољим ковачем матерњег језика”.

Чврстог сам уверења да је управо Бранко Радичевић песник - ковач, онај што кујући стихове искива нове речи, даје језику оно што му је потребно и у том времену важно. Он је први српски поета који брине о речима. Док их Вук скупља, Бранко у својој поезији им одгонета права значења. Истовремено, правећи музикалну поезију иницира судбоносни сусрет лирске и музичке културе на тлу заједничког језика.

Његово следбеништво, братство модерних трубадура, упорно и доследно трага и за речима и за музиком, знајући колико је он чудесно врело те две тежње. 
При томе ваља рећи да је Бранков језик ретко служио за писање већих прозних форми, рађе је своје могућности и разиграност нудио поезији и песницима. Тај је језик, више него музика, све време имао педагошку и охрабрујућу улогу, па чак и када се поезија трубадурске или песмотворачке братије одвоји од музике за коју је писана, она не губи много од своје вредности.

И ту је та чаролија.

Сваки трубадур има свој језик, али се не устеже да у стихове уведе и неке речи из дијалекта који није његов. Додајући песничком чину врсту ванвременског печата, најбољи међу минстрелима успели су да направе поседе веће од земаља својих владара. То им ниједна будућа власт ни системи силе нису успели умањити или одузети.

Ваља рећи да се у сусрету поете и музичара стварао, усавршио и учврстио један код части и истовремено храбар говор присутног сведока. Нешто се од тога чуда, код најбољих, упркос разним искушењима сачувало до дана данашњег.

Рок поезија може и хоће оно што папирно песништво није могло и знало, а то је изаћи из затвореног и са свих страна омеђеног простора унутрашњих фасцинација, бити отворена и александријски изазовна, широка а истовремено комуникативна на начин да отпевани стих може прерасти у заједничку обредну заоставштину.

Како је рокенрол шездесетих година почињао да се све више од стране самих практиканата доживљава као аутентична вредност, тако је и растао интерес за његов текстуални садржај. Почетна форма усмерена пре свега на забаву, временом је освојила важност нудећи Став и Поруку. То што се рок обраћао ширем, шаренијем и разнороднијем аудиторијуму, захтевало је да се неке ствари искажу директније, тиме и далекометније: резонанца отпеваних стихова била је већа од домета политичких говора, а наизглед наивност употребљених метафора 
вратила је сентиментални, аутентични квалитет искрености, чак и неким „истрошеним темама”. Ту специфичну позицију снаге певаног текста најбоље су искористили талентовани и мудри, спајајући на чудесан начин богатство језика са циничним односом поколења из ког долазе у простор између апсолутне лирике и иронијске дистанце.

Не пева се и не пишу песме само да би се променио све суровији свет и рекло нешто пресудно ново, већ да би се оправдала и потврдила сопствена егзистенција. Постоје још међу нама људи који не знају ништа друго него да певају. Стваралац је занесењак, власник доживљаја, усхићења и значења која придајемо појединим осећањима, сликама, бојама и звуцима из наших живота. То је заједнички раствор за дисање и деловање у који утапамо наше идеале, наде, страхове и чежње.

Од Радичевића се судбина својих песама живи. То је крајња судбина поезије: Стварност стварнија од видљиве стварности, радост узвишенија од обичне радости, али и бол несноснији од најдубљег бола.

Традиција песничког говора у овдашњем року вуче јасан траг од Родоначелника преко Дедића, Трифуновића, Млинареца, Глишића, Топића, Бреговића, Штулића, Балашевића, Шобића, Шифрера, Бајагића, Предина, Младеновића, Хоуре, Стублића, Карајлића преко Рамба, Цанета, Кањевца, Крстића, Џибонија и Кебре до СТ-а, Врањковића и Марчела.

У том низу Бора Ђорђевић је посебан случај.

Крајем '76. кроз групу Сунцокрет оглашава се песмом „Успаванка” у којој је могуће препознати неоспоран Радичевићев утицај:

Најлепше снове на свету саньаш / санај да летиш, да имаш крила / док ноћ на небу тагано плови / саньј, бићу крај тебе. 


\section{Мораш бити ломљен}

\section{да би се светлост могла пробити}

Деценијама, иако све време под унакрсном ватром између еуфорија и оспоравања, тај и такав јесте поета од класе. Пажљиво читан и слушан, цензурисан и прећутаван, никад није заустављем. Ударан, али несрушен.

Увео улицу у песму, рокенрол извео на булевар, одатле све скупа одвео у политику и даље до стварне линије фронта и многих заједничких разочарања. И отрежњења.

Сматрао је питањем части да сто посто личи на своје песме. Писао је и певао оно што су многи у тишини мислили, али без дара и петље да кажу и потпишу. А кад отвори душу, пошто је свака права песма спој измереног и неизмеривог, Бора не само да одере властиту кожу већ и на длану понуди пулсирајуће срце.

Док 1979. Горан Бреговић филозофски признаје „пристао сам бићу све што хоће, после ове игре кад ме сломе”, Бора, снимајући први албум, поручује „против мене лека нема" унапред оглашавајући спремност да учествује у свим играма сламања.

Главни јунак саге о Риблој чорби и зачин многих других љутих чорби, никад не размишљајући о цени остао је веран својој збуњујућој природи. С једне стране лидер највеће српске групе, с друге сведок и актер у слому Југославије, година расплета, рата и примирја, слободе, транзиције и овога што се управо догађа. Колико бриљира, толико уме да брља све личећи на свој неоседлани народ. Одгајен на сумњивим митовима, сумњивим победама и несумњивој уметности (песник се не постаје него рађа), истовремено васпитан да је неправда ДНК заједничке судбине. Србин пустошне осетљивости могао је бити све у уметности што је демонстрирао као песник, новинар, глумац, писац, говорник, афористичар, забављач и културни делатник, али је запосео позицију гласноговорника и дужност новоусменика прећутане стране живота. 
Гаврош са барикада свих наших неспоразума. Шумадијски разарач што предуго делује у чудесном лавиринту естрадне политике и крајње политизоване естраде. Општенародно добро што оре по градском муљу без амбиција да се дистанцира и први рокенролер потпуно окренут националним питањима.

При томе на олтар истине полагао крв, љубав и псовке. Његова несумњива даровитост, наквашена пороцима и страшћу, уме да закорачи у профаност, али је увек довољно моћна да посведочи о побуњеном духу човека у времену страха од нејасне прошлости и претеће будућности. Та песма израсла из асфалта и беса, као да у његовом случају и нема смисла ако би била другачија. Сa усхићењем детета чисте емоције, поседујући ретку виспреност и оптику која га чини свенародним заступником, и даље је способан да се у неколико минута озбиљно потврди као власник песама за сваку ситуацију.

Какав је пример оседели бард и суверен незаборавних рима?

И даље рокенрол доживљава као либрето, а не канон за могућност живота! Здравствено озбиљно окрњен, аутентичан и популаран, отписиван и лајав, често судски гањан, али неугањан, устао више пута него је срушен. Без обзира колико награђиван и цитиран, пословно је неспособнији него што га диплома ФДУ обавезује. Много тога је учинио да се упропасти, а није успео. Увек испливава из вирова предвиђених за дефинитивно уроњавање. Каријеру гради и разграђује мимо логике.

Мада удаљен од некадашње браће, бивших љубави и кафанских пајташа, простор његове речи сразмерно се не урушава као што се смањују свете територије за које се искрено залагао.

Уважени Игор Мандић је то предвидео још 1988. пишући у Политици: „Ђорђевић је пјеснички изричај јединствен у нашој култури, па и књижевности. Он је 
запосео свој дио на сцени актуелног нашег пјесништва и више га нитко одатле неће помакнути."

Свет градске маргине, тешко уклопљив у веродостојне статистичке моделе, који Бора није прећутао заправо је свет највише настрадао у прелому осамдесетих и деведесетих. Људи широке душе и поводљивог срца први су највише платили. Њему је, као човеку из близине, пало у обавезу да опева најтеже време, доба осионости, неправде, насиља и нељудскости.

Поетика пустошне осетљивости омогућила је Бори огроман пасус у историји српског рока. Кад се уз рокенрол претоварио кафанским, швалерским, навијачким, геостратешким, патриотским и религиозним задацима све до седења у недостојним телевизијским жиријима, многе ствари за које се у 281 објављеној и отпеваној песми борио, од првобитних поштовалаца доживљене су као тотална издаја. При свему томе његова обдареност умела је да послужи за легализацију вулгарности српске јавне сцене. Неуштројени бандоглавац је тај немузички пут платио губитком озбиљних симпатија. Тако бива кад рука остаје ближе срцу него глави.

Захваљујући песмама Бора је крочио у жижу јавности. Данас се Ђорђевићу песме вреднују због сандраровског хода кроз властиту биографију.

Каријеру и даље носи споријим кораком борећи се за право да, до самог краја, буде свој: Човек са вишком асфалта у венама и Србије у срцу. Давно заклаћени шампион остао је на ногама после свих дуела са стварношћу. Иза њега стоје највећи тиражи, највише највећих концерата, низ антологијских песничких захвата и Погледај дом свој, анђеле највећа српска рок песма ХХ века.

Пишући препоруку за Удружење књижевника Србије, Матија Бећковић је констатовао: „Оно што сви виде разлог је његове широке популарности, а оно што је невидљиво и што је осећају само позвани и упућени - доказ његове вредности." 
Ове речи крију једно од објашњења четрдесетпетогодишње тајне успеха Боре Ђорђевића.

Свеприсутни аутор у пет, а заправо у једном истом систему (током Тита, колективног председника, Милошевића, демократских транзиција и Вучића) личним примером је доказао савршену способност да никад не изневери себе уз истовремену спремност да највише науди сам себи. Као сваки прави кафањерос, због репутације, платиће цех и за оно што није конзумирао.

Но, слава је одувек супа са пуно длака на површини.

Лајање у свим правцима кошта. Што рече и отпева Арсен Дедић: „Тешко је мом другу часном Бори Чорби, глава му на рамену, а он би хтио да му је у торби.”

Но, одувек је тако са трубадурима: пада им у дужност да крвљу и кичмом сведоче о времену урушавања бројних снова и озакоњеног лудила.

Волели га или не, Ђорђевић са 24 албума, десет књига, осам постава Рибље чорбе и свим трофејима који овде постоје, иза себе оставља сложену слику неисконструисаног живота, велики аутентични корпус „стварносне урбане поезије” прерасле у класичну заоставштину једног времена.

Утицајан као ослободилац простора и говора, Бора је остарио омогућивши наследницима да не ћуте.

\section{Упркос свему, поезија ће остати крик слободе}

И тако, без икаквих поређења, стижемо до Марка Шелића. Људи који не знају Марчела, једног од најпопуларнијих музичара у Србији, хип-хопера, писца, сценаристу и колумнисту, оптерећени предрасудама често говоре да је исти као они који се баве таквом врстом музике - значи „уличар” или „пропалитет”. Марчело јесте „пропалица” што се усуђује да песмама јасно покаже 
своје мишљење, пошто „Око себе видим само понижену памет на рубу егзистенције и разбахаћени шљам, уз оно мало средњег, једвакопрцајућег слоја. Све у свему, не верујем да је једина сврха провући се кроз живот са што мање невоља и једноставно нестати."

Поред неизбежне усамљености, уметник ове и овакве стварности, као и сваки мислећи човек, осећа патњу због понижености. Зато, бранећи свој ход по другој страни улице ковач потресних а јетких сведочења, враћајући се и сам Радичевићу, јасно каже: „Моје песме у суштини такође представљају уримоване приче. Мораш да даш своје месо да би та прича имала икакву тежину. Ако се не чује да то говори особа, неко ко и самога себе ставља под лупу, ко је спреман да и себе сецира колико и друштво, онда је све само празна проповед коју изговара андроид који пати од умислице да је морални апсолут. Дати своје месо, бити спреман да самог себе покидаш и видиш чега све има унутра, посебно у ћошковима, у мраковима само такав заслужује да га ослушнемо кад упери прст у нешто друго. Не верујем ауторима код којих не видим макар неку врсту стриптиза душе. Ако желиш да расецаш свет, најпре распори себе."

„Ја сам све што кажете да јесам - и још горе од тога. И да нисам - јесам. А шта имам од тога? - Само бол и револт."

И шта рећи за крај?! Судбина песника, без обзира на њихову различитост, у сваком од наших модерних времена је слична.

Шта је заједничко у тој поетској линији од Бранка преко Боре до Марчела?

Сазнање да нема власти спремне и наклоњене за такве таленте и слободу којој они теже. Бранко Радичевић за живота није успео да прошета омиљеним Београдом. Стигао је до савске Ђумрукане и одатле заувек протеран. Бора Ђорђевић је највише од свих колега пред- 
стављао своје стихове по судовима, док Марко Шелић због дужине језика практично није пожељан у својој рођеној земљи.

\section{Predrag Peca Popović}

\section{POETRY, MUSIC AND FATES - FLOATING RIBS SPROUTS FROM BRANKO RADIČEVIĆ}

This paper analyzes the interrelationship in the poetry of Branko Radičević, as the founder of Serbian lyric poetry, as well as his contemporary followers: Bora Đorđević and Marko Šelić Marčelo. There is an illustration of the common, not only in their poetic stream, but also in their fates. And the poet's fate, as the author emphasizes, is similar, regardless of their differences in every segment of our contemporary time. Among the three mentioned poets, alongside with his 24 albums and ten books, Bora Đorđević also left behind a complex visual of unstructured life, a grand authentic corpus of "real urban poetry" that has evolved into the classical heritage of a specific time period. 